\title{
Dnipropetrovsk National University named after Oles' Gonchar
}

\author{
Olexandr Pakhomov \\ Department of Zoology and Ecology, Biology, Ecology and Medicine Faculty, Dnepropetrovsk National University, \\ Gagarina av., 72, 49010 Dnepropetrovsk. Ukraine
}

Keywords: University, establishment, higher education, sciense.

\section{SUMMARY}

The Dnipropetrovsk National University is a multi-profile educational and scientific complex, where 16 faculties, the faculty of continuing education, the faculty of correspondence and distance education, post-graduate courses, doctorate, three scientific research institutes, 107 sub-faculties (departments) function, where about 1300 teachers including 150 Doctors of Science, professors and about 700 Candidates of Science, associate professors. In Dnipropetrovsk National University 15,000 students study majoring in 64 fields of knowledge and also foreign students and post-graduate students from more than 20 countries of the world study there. The educational and scientific process at the university correspond to the highest levels of the home and world standards.

\section{RESULTS AND DISCUSSION}

Dnipropetrovsk National University is one of the most well-known and prestigious higher educational establishments in Ukraine which is celebrating its 90th anniversary.

The University was founded in 1918 on a difficult and at the same time bright way to its dynamic development. Dnipropetrovsk National University is rightly proud of its enormous army of students. During the period of its existence 120,000 specialists have graduated and without them it is hard to imagine any sphere of our social life. Among the graduates of DNU are: statesmen and social workers, managers of enterprises, educational, scientific and cultural establishments, commercial structures, outstanding scientists, teachers, journalists.

The most famous of them are L. D. Kuchma (The President of Ukraine from 1994 to 2004), the Prime Minister of Ukraine U. V. Tymoshenko, Director of National Safety Problems University - Academician V. P. Gorbulin; famous writers: heroes of Ukraine - O. T. Honchar and N. G. Zagrebelny, general designer - general director of the State Enterprise «Design office «Pivdenne» named after M. K. Yangel» - Academician S. M. Alexeev, O. M. Trubachov, V. I. Mossakovsky, V. V. Pylypenko and many others.

From the history of University. 90 years ago in tempestuous 1918 due to the initiative and support of famous Ukrainian academicians V.I. Vernadsky, D.I. Bahaliy, L.V. Pysarzhevsky, M.P. Vasylenko in Katerynoslav there was established the first classical university comprising four colleges: historical and philological, law, medical and physical and mathematical.

The first elected President of the University was a famous scientist biologist, Professor V.P. Karpov. The first steps in the development of the establishment were made by such distinguished people as V.O Bidnov, V.E. Dzerzhinsky, O.M. Dynnik, P.O. Efremov, L.L. Ivanov, M.I. Lebedev, M.K. Liubavsky, L.V. Pysarzhevsky, L.V. Reyngard, F.V. Taranovsky, DI. Yavornytsky and others.

In 1920 a new government reorganized the educational system of the USSR, and as a result the Institute of Public Education was established on the basis of classical universities among them is Katerynoslav University. Since 1933 the National University of Dnipropetrovsk resumed its work. The educational establishment was slowly getting stronger, becoming the leading higher educations establishment of the region.

Scientific research in different fields of knowledge, especially in theoretical (electronic) chemistry (academician O.I. Brodsky), physics of liquid (academician V.I. Danylov), applied mathematics (academician M.O. Dynnik, metal physics (academician G.V. Kurdiumov) hydrobiology (academician D.O. Svirenko) history of Ukraine, archeology and ethnology (academician L. I. Yavornitsky) enriched the Soviet science noticeably, had become an important basis for establishing scientific schools not only in Ukraine, but also abroad.

During the World War II and permanent occupation of the city was damaged, but educational process in the University went on. There were 7 colleges at that time: physical-mathematical, biological, chemical, geological and geographical, historical, philological, foreign languages, where 540 students studied.

During the first pre-war decades, facing great difficulties, the staff of the university, turned it into one of most dynamically growing educational establishments in the country. Scientific, facilities and staff potential enhanced noticeably. New scientific schools in the fundamental and applied fields of knowledge appeared, scientific research colleges, departments and laboratories were established.

During the last years due to the efforts of leading scientists and the whole teaching staff there is a great development of widely known schools of mathematics, mechanics, radio-physics and radio-electronics, rocket and techniques, space techniques, neuro-cybernetics, biotechnology, inorganic chemistry, historiography, history 
of Ukraine, archeology, germanistics, language and literature research. As a result of such remarkable achievements the international society shows great interest in the university. The indicator of it is the spreading and establishing of international links with educational and scientific establishments of the world.

The University Today. Today the university has four higher educational establishments of the first and second levels of accreditation, sixteen faculties, forty six research laboratories, three research institutes (biology, geology, energy engineering), a faculty of continuing education, a faculty of continuous education, a faculty of part-time and distance education, a faculty of preparatory entrance training (including the foreigners), a regional centre of continuous education of "Pridniprovja", a centre of humanitarian educational problems.

The preparation of specialists in the university is carried out by full- or part-time or by external forms of education in sixty-four specialties.

According to the license in DNU preparation of Bachelors, specialists, Masters (including the foreigner citizens) is carried out.

Approximately 15 thousand students study at the university, over the 10 thousand of them are full-time students.

Among the teachers of the university there are two members-correspondents of National Academy of Sciences of Ukraine and two correspondent members of Academy of Pedagogical Sciences of Ukraine, 22 academicians and 4 correspondent members-of foreign academies, 75 collaborators are awarded honorary titles "Excellent educators in Ukraine", 28 are awarded honorary titles "Honoured public worker of science and technology of Ukraine", 27 got the title of "Honoured worker of national education in Ukraine", 6 are awarded the title of "Honoured worker of culture of Ukraine".

The achievements of the university are noted by numerous government and industry awards, prizes, grants of the foreign scientific and educational institutions.

The Scientific schools, well-known in Ukraine and abroad that have the necessary personnel and provide significant potential for its development, were formed. The scientists of the University annually publish more than two dozen monographies, nearly 2,000 scientific articles and nearly 3,000 manuals. The Patent fund of the inventors counts almost 1 for 600 patents and copyright certificates and every year it is added by dozens of new inventions.

Near 50 contracts about the scientific cooperation with the higher educational institutions and scientific organizations of the countries of Europe, Asia, USA, Canada are realized nowadays.

The students and postgraduate students from the university study abroad, and the professors have internships. The intensive exchange of scientists and students is made.

About 100 professors and teachers go on business trips abroad annually. The foreign professors of Japanese, Chinese and German languages work constantly.

Almost 5,000 students are involved in different forms of scientific work. They publish more than 200 articles annually; get more than 40 awards at the competitions. There are the fixed bases for practice work in Kocherezhky and Andriivka at the university.

International Cooperation. Dnipropetrovsk National University has successfully developed contacts with international educational and scientific institutions. Since 1994 DNU has actively taken part in elaboration of international scientific projects of such funds and programs, as TEMPUS, "Vidrodzhennya" ("The Renaissance"), "Dnipro" ("The Dnieper"), "Public education", Soros Foundation etc. Our university won 10 scientific TEMPUS projects, the total grant support of which has comprised about 2,000,000 USD dollars . At present there are two TEMPUS projects which are being elaborated in DNU.

In 2007 Dnipropetrovsk National University, being a member of a consortium of institutions of higher education from Ukraine, Moldova and Belarus, got the European grant of academic exchange - "Erasmus Mundus". This program provides for exchange of students, postgraduate students and those working for Doctor's degree. It is fully financed by European Commission.

Presently DNU has made about 50 cooperation contracts in the sphere of students and faculty exchange, joint scientific research, cultural exchange with the foreign partners from Germany, France, Sweden, Spain, Italy, Poland, Turkey, Bulgaria, Latvia, Brazil, the USA, Canada, and China. International education community expresses a great interest in DNU. In fact, DNU is constantly visited by foreign delegations from the different countries of the world.

International education community expresses a great interest in DNU. In fact, DNU is constantly visited by foreign delegations from the different countries of the world.

International exhibitions and conferences are annually held in Dnipropetrovsk Nationally University.

More than 100 teachers and students of DNU are annually sent abroad as the participants of conferences, symposia, exchange programs, joint scientific research and for giving lectures.

The teachers of DNU are members of international organizations, among them is the President of Dnipropetrovsk National University, Professor, Member of the Academy of Sciences of the Higher School of Ukraine M.V. Polyakov who is a member of American Mathematic Society; Corresponding Member of the National Academy of Astronautics. DNU has been a member of Eurasian Association of Universities since 1998, European Collegiums of Polish and Ukrainian Universities since 2002, and Eurasian Forum since 2005. This 
membership gives the University great possibilities to cooperate fruitfully with foreign institutions of higher education and widen the geography of international relations. All this helps to increase the quality and effectiveness of scientific and academic activity of DNU.

DNU Scientific Schools. Among all kinds of research activity fundamental scientific investigations aimed at searching for the new rules, fundamentally new phenomena in nature and society rank as the most important ones. They determine intellectual level of the society and degree of its willingness to use modern achievements, open up new fields of applied research, experimental design developments and innovations.

Scientific schools of thought of DNU are known in Ukraine and abroad for considerable potential possibilities. Among them are:

Aero- and hydromechanics

Molecular gas dynamics, aerodynamics of aircraft, vortex flows, heat-mass exchange in porous medium.

Mechanics of deformed solids

Theory and methods of applied tasks solution of elasticity, plasticity and design reliability.

Physical materials technology

Rules of phrase modifications, forming of structure of metal materials, coating and wash. Non-melt technologies of deoxidizing agents, addition alloys and conditioning agents for steel and alloy production.

Physics of active dielectrics and elements on their basis

Monocrystal materials for acousto-optic electronics. Ferroelectric photo effective crystal growing.

Theoretical and computational neurosciences

Research of fundamental rules of connection between structure and functions of nervous system on molecular, sub-cellular, cellular and system-defined levels of organization using mathematical modeling and information technologies.

Fundamental and applied problems of rocket-space equipment development and use

Theoretical research and development aimed at improvement of functional features of the industry's products.

\section{Research of extremal problems of approximation theory}

Research related to extreme problems of theory of functions and functional analysis.

Steppe dendrology and forest restoration of soil

Solution of problems related to steppe dendrology which is the basis of steppe forestry and forest restoration of spoiled soil in Ukraine.

\section{Molecular biology and physiology of plants}

Scientific research on physiology and biochemistry of plants, molecular biology, ecology, introduction and acclimatization of plants on the basis of the diagnostic techniques of functional state of plants under the chemical stress conditions.

\section{Physiology and biochemistry of microorganisms}

Theoretical research on microbiology, virology and biotechnology, development and application of preparations on the basis of bacteria and fungi.

\section{Water and radiation ecology}

Study into processes of water quality formation and bioproductivity under conditions of anthropogenic eutrophication, toxic and radionuclide pollution of water.

Structural-functional zoology

Solution of the most important issues of modern zoology and ecology. The research is aimed at studying zoo enosis as a structural-functional component of biosphere.

\section{Electric precipitation and metal corrosion prevention}

Metal plating, surfactant admixtures, methods of research on electro-crystallization of copper monolayer. Theoretical basis and technologies of foil of wide spectrum of thickness, bearer-protectors and special coating production.

Epoxies

Methods of synthesis and reactivity of epoxies compounds of alicyclic series, theoretical conception about olefins oxidation reactions and epoxidation of organic compounds, machinery of epoxidation reactions, biological active substances on the basis of wireframe epoxy compounds.

Geology of sedimentary deposits of Cainozoe in Southern Ukraine

Revealing stratigraphic structure and correlative connection of Neozoic strata in the South of Ukraine adjoining territories. Reconstruction of historic development of region and its organic structure in the past geological times, creating stratigraphic basis for wide-ranging mapping geological times. Creation of stratigraphic basis for scale cartography.

Anthropological and methodological aspects of historical and philosophical studies in the context of national philosophy

Investigation of the anthropological aspect of historical and philosophical studies, methodological aspects of historical and philosophical science as well as problems of national philosophy and the influence of national philosophy on historical and philosophical process.

General and educational psychology 
Methods of substantiation and development of means of computerized diagnostics of personal emotional and cognitive spheres.

Historical Ukrainian studies of the $16^{\text {th }}-20^{\text {th }}$ - centuries

Social, political, military and political history of Ukraine, archeology of Ukraine, historiography and source study of Ukrainian history, ethnology of Ukraine, contemporary Ukrainian and German ties.

Scientific Library. Honchar National Dnipropetrovsk University Scientific Library is one of the biggest among libraries of different educational establishments in Prydniprovsk region. The main fund has over 2,2 million samples. The seven-storey building (total area of which is 12260 square meters) decorates architectural complex of university's educational buildings.

Through the year the library is visited by more than half a million users, to whom nearly 1 million 400 thousand books are given.

A local library computer network is created and functions. Almost 35 thousand titles of new books and 80 thousand of bibliographic records were introduced into the electronic catalogue. Since 1996 according to rating of work the Scientific Library is ranked as the library of category 1. DNU Scientific Library is a treasury of knowledge for thousands of users.

Botanical Garden. Founded in 1931, botanical garden is a scientific, educational establishment and a conservancy of DNU. The ground area of the garden is 33 hectares.

The collection of alien plants consists of more than 3000 species, forms and varieties.

The botanical garden is a member of International Council BGCI (botanical gardens protecting plants, Kew, England) and IABG (International Association of Botanical Gardens, Kew, England). A great work is held of sharing collections of seeds, cuttings and plants with other botanic gardens of Ukraine, of the far and near abroad.

Aquarium. On the territory of Ukraine there is a single unique complex of freshwater fauna, which has no analogues, - Dnipropetrovsk Aquarium, which is located in a picturesque place on the Monastyrsky island. Due to its appointment, it serves as a live museum of freshwater flora and fauna with the closed cycle of animal development.

On the basis of the aquarium, an outreach centre of aquatic ecology of Prydniproviie was created. Teaching and research complex "Aquarium" holds a significant excursion activity (lectures on environmental issues, lectures, expedition trips), aimed at spreading environmental awareness among the population.

The unique collection of freshwater fish and plants is constantly replenished. There are about 20 species of river fish from the Black Sea basin and about 60 species and varieties of aquaria fish, 5 species of amphibians and reptiles.

Zoological Museum. Zoological Museum as a scientific, educational and cultural unit of the University was founded in 1924 to study rare and typical species of local and world fauna by the creation, renovation and preservation of zoological collections. Total number of exhibits is about 7 thousand, which are represented by 961 species, 86 of which have almost disappeared from the wildlife and are listed in the Red Book.

Culture, sport and recreation. The university has an educational and cultural complex "DNU Student Palace", which was recognized as a historical and architectural sight of the national significance by the governmental decree. In 1961 it was named after the first cosmonaut of the Earth Yury Gagarin.

It is difficult to imagine students' life without this palace. It has big and small halls for 500 and 150 spectators, greeting halls and rehearsal rooms.

24 amateur artistic groups work here, 13 of which have an honorary title "People's" or "Exemplary". They are well-known not only in our city but also far away from it. The best artistic amateur talent groups have taken part in the final concert of Ukrainian festivals of folk creativity in the National Palace "Ukraine".

32 clubs and function in the Student Palace. Almost 1 thousand students come there, nothing to say about teaching staff and their members of the families. майже 1 тис. студентів, не враховуючи викладачів та членів їх сімей.

Sports Centre. The university has a modern sports centre where 7 sports halls, a swimming pool a children pool, a fencing hall and sports grounds are located. There are 30 sports groups in different kinds of sports where approximately 500 students are trained; there is also a school of Olympic reserve for children and youth on water polo (200 people), a health camp which is regularly visited by 2 thousand students, employees and the members of their families.

Our pride is masters of sports of international qualification - a World champion in karate Ihor Karavainov, a European champion in badminton Larisa Hryha, a Silver European champion in athletics Yu.Akulenko, a member of Olympic national team in Beijing Yuryi Shliahov and many other prominent sportsmen - alumni of Dnipropetrovsk National University.

University sports - health camp "Sosnovy Bir" (Pine Wood). University sports - health camp "Pine Forest" which is located in one of the most picturesque places of Dnipropetrovsk region may receive 240 holidaymakers at once. Annually about 800 people have a vacation in the sports-health camp.

Annually 850 students improve their health in the sanatorium-preventorium. Qualified medical staff is at their disposal. 


\section{REFERENCES}

http://www.dsu.dp.ua/

Історія Дніпропетровського національного університету / Голова редколегії проф. М. В. Поляков. - 4-те вид., переробл. і доповн. Д. : Вид-во ДНУ, 2008. - 308 с.

Професори Дніпропетровського національного університету імені Олеся Гончара : Біобібліограф. довідник / Голова редкол. проф. М. В. Поляков. - 2-е вид., перероб. і доп. - Д. : Вид-во Дніпропетр. нац. ун-ту, 2008. - 596 с.

Ми - $з$ класичного університету. Дніпропетровський національний: час, події, люди // За заг. редакцією проф. М. В. Полякова. - 2ге видання, доповнене, перероблене. - Д. : Вид-во Дніпропетр. нац. ун-ту. - 2008. - 148 с. 